\title{
Элементы традиционного культурного ландшафта белорусов как средство объективации истории
}

\author{
Владимир Лобач \\ Полоцкий государственный университет \\ nordic972@gmail.com
}

\begin{abstract}
Аннотация: Природные и антропогенные объекты традиционного культурного ландшафта выступают в мифопоэтической картине мира своего рода «закрепками» коллективной памяти и жизненного опыта, которые постоянно верифицируют и актуализируют в синхронной перспективе прошлое в наиболее значительных для сообщества срезах. В рамках белорусского традиционного общества чрезвычайно важной символической функцией культурного ландшафта является объективация истории. Однако сам механизм отбора и фриксации исторических событий, который включает в себя реальный объект жизненного пространства и фольклорный информационный блок, с ним связанный, принципиально отличается от логики и принципов «письменной истории». В рамках локального сообщества первичным и важным становится знаковость того или иного исторического события для «местной истории», а ее точная хронологическая соотнесенность несущественна и вторична. В первую очередь, ландшафтная объективация «обрабатывает» и фиксирует мифологические прецеденты и исторические события эпохального характера. Персонализация прошлого на разных уровнях ее актуальности в проекции на локальный культурный ландшафт делает последний своего рода историкоцентричным, когда наиболее сущностные исторические события (от библейского потопа до войны с Наполеоном) происходят в околицах конкретной деревни. Коллективная память не только
\end{abstract}


наглядно и доходчиво объясняет события прошлого посредством фольклорных легенд, соотнесенных с элементами ландшафта, но и "вписывает» местную историю в качестве центрального сюжета истории глобальной как в ее библейской, так и мировой версии.

Ключевые слова: культурный ландшафт, мифология пространства, фольклор, история, белорусская традиционная культура, объективация истории, сакральная география

\section{Введение}

Вопрос об «историчности фрольклора» и, соответственно, историчности традиционного сознания как такового, исследуется и дискутируется в течение последних десятилетий, что отражено в работах В. Я. Проппа, Б. Н. Путилова, А. К. Байбурина, Г. А. Левинтона и др. Основное внимание при этом было обращено на «эпическую историю», вербализованную в классических фольклорных текстах различных культурных традиций. Принципиально важным стало понимание того, что фольклор не является непосредственным «эхом давних времен», но «доносит до нас не столько информацию о прошлом, сколько матрицы общественного сознания, зачастую имеющие мифологический генезис (точнее, исторические воспоминания, отобранные и структурированные сообразно данным матрицам)» (Неклюдов 2007: 77).

Фольклорное сознание имеет собственные принципы и механизмы создания истории, которая, безусловно, отличается от истории письменной. Речь идет о двух различных типах истории, где фрункционируют разные механизмы объективации событий прошлого. «Фольклор и история понимаются в самом широком смысле: как различные способы коммуникации, воплощения, описания и систематизации в пространстве и времени «реалий» бытия. Противопоставление «фольклора» и «истории», воплощающих соответственно устную и письменную традиции, «синхронные» - в пределах одного поколения, коллектива или даже речевого (обрядового) акта - и «диахронные» (между поколениями и эпохами) способы коммуникации, условно уже в силу того, что и фольклор призван воплощать традицию - память поколений. Другое дело - как реально действует механизм этого воплощения, и это - одна из самых сложных проблем славянской 
фольклористики и истории славянской культуры в целом...» (Белова \& Петрухин 2008: 3-4).

Механизм кодификации и мемориализации исторических событий в культурах фольклорного и письменного типа существенно отличается. Для письменной истории важной становится хронологическая последовательность, фрактическая подробность и достоверность («истинность»), которая верифицируется «историческими источниками». Одной из определяющих черт письменной истории является ее авторский характер. В свою очередь, отбор и интерпретация исторических фрактов носят субъективный характер от самых начал письменной истории, как бы ее авторы ни настаивали на «объективности».

Для традиционного сообщества свойственна цикличная организация времени, тесно соотнесенная с природными (аграрными) ритмами, что снимает необходимость в точном хронологическом измерении и фиксации реальных событий в общем фонде коллективной памяти. Достоверность исторического (местного, топонимического) предания для его носителей и потребителей заключается не в строгом соответствии историческим реалиям, но в том, насколько мотив, сюжет и действующие персонажи конкретной «истории» вписываются в традиционную картину мира, свойственную определенной этнокультурной традиции. «В сознании фольклорного «потребителя» и вообще в коллективном сознании «фольклорной среды» существовала постоянная нужда все время снова моделировать уже установленную традицией картину мира, устанавливать все окружающие объекты, явления, события на свои места и тем самым избегать внутренней дисгармонии» (Жукас 1982: 79).

В рамках традиционного сообщества, фольклорного по способу фиксации и передачи информации, а также «анонимного» в смысле авторства, задача отбора и интерпретации исторических фактов специально не ставилась, поскольку ее реализация была целиком «автоматизирована» мифопоэтической картиной мира. Цикличное восприятие времени, свойственное традиционному мировоззрению, нивелировало значимость любых дат, твердо привязанных к линейной модели истории с ее точным хронометражем. При этом первостепенную значимость приобретала именно «местная история», которая являлась единственно реальной для локального сельского сообщества, но могла быть масштабирована до уровня истории глобальной или библейской. 
В качестве механизма фольклорной мемориализации истории выступает традиционная картина мира, для которой существенны и значимы только прецеденты, события переломные, критические, экстраординарные и именно в местном измерении. «Фольклорно-исторические» предания, составляющие значительный пласт устной истории, предоставляют исследователю народной картины мира богатейший материал для размышления над тем, как виделось нашим предкам географическое и политическое устройство мира, что было актуально и релевантно с точки зрения "истории места», а что проходила незамеченным» (Белова \& Петрухин 2008: 7).

Исторические представления в традиционном сообществе довольно далеки от обобщений и масштабности (история страны, народа) и касаются преимущественно «своего» мира - одного или нескольких поселений с окрестностями. При этом элементов локальной топографии с избытком хватало мифологическому мышлению как для вербализации конкретных фольклорных сюжетов, так и для структурирования сложной и детальной картины мира. Как отмечает Р. Радзик, историческая память белорусских крестьян «опиралась на устную традицию и имела, прежде всего, характер локальный, в значительной степени соотнесенный с топографией» (Radzik 2000: 174).

Вместе с тем, все прошлое, усвоенное коллективной и индивидуальной памятью, отчетливо делится на два неровных по своей глубине слоя. История актуальная (оперативная) обслуживается совокупностью личных воспоминаний (например, о событиях II Мировой войны) и характеризуется не только множествам подробностей и определенных деталей, но и личным эмоциональным отношением сказателя к тем или иным событиям, которым он дает собственную оценку либо интерпретирует, но в любом случае убежден в их реальности. История легендарная (эпическая) никогда не является итогом собственных воспоминаний человека, но есть продуктом ретрансляции информации («еще деды дедов рассказывали») о событиях очень давних («давным-давно»), которые измерить точной хронологией невозможно.

История легендарная лишена (или почти лишена) эмоционального отношения сказателя к событиям, которые там фригурируют, и имеет характер констатации («Говорили, Бог ходил по земле...»). Для истории этого типа существенна не 
столько историческая точность в ее классическом понимании (даты, фракты, персоналии), но соответствие зафиксированных коллективной памятью событий структуре и логике картины мира в ее пространственном и временном измерении. Это вовсе не означает, что актуальная история, в противовес легендарной, является абсолютно реалистичной и антифольклорной. Былички - истории о личной встрече человека с представителем иного мира (чертом, призраком или русалкой) - не менее фольклорны, чем легенда о великанах. Однако приоритетным «собственником» легендарной истории является коллективная память («говорили, что...»), сфокусированная в нарративе конкретного сказателя, в то время как актуальная история, в первую очередь, принадлежит личной памяти («помню, что...»), хотя и в проекции на историю всего коллектива.

Ошибочно считать, что два среза коллективной истории обособлены друг от друга и никоим образом не пересекаются. Восприятие времени в культурах фольклорного (традиционного) типа не предполагает наличия однозначных хронологических рамок, границ: прошлое может перетекать в будущее и настоящее. История легендарная (эпическая) активно пополняется за счет истории актуальной, когда очень значительное для локального сообщества событие с течением времени (жизнь 3-4 поколений) максимальным образом фольклоризируется и переходит в категорию исторических преданий. С другой стороны, «факты» истории легендарной периодически верифицируются в рамках современных деревенских актуалий. Например, церковь, которая якобы провались под землю в незапамятные времена, образовав Святое озеро, реально, по убеждению рассказчика, напоминает о себе звоном колоколов и в наши дни.

У Лепілі во, гаварылі, што Святое возера называецца. Сьвятое, што вот правалілася царква там, у тое азяро. Гэта есьлі купацца - нельзя там, што ўсераўно туды утопішся. Там ад берага глыбока зразу, кажуць. I ўродзе гаварылі, што ў Паску там чуваць, што званы звоняць, у тым азяры (Лепельский р-н Витебской обл.) (ПЭЗ 2011: 169).

Приведенная цитата указывает на очень важный фрактор мемориализации истории в рамках локального сообщества - элементы традиционного культурного ландшафта выполняют информационные функции не только в синхронной, но и диахронной 


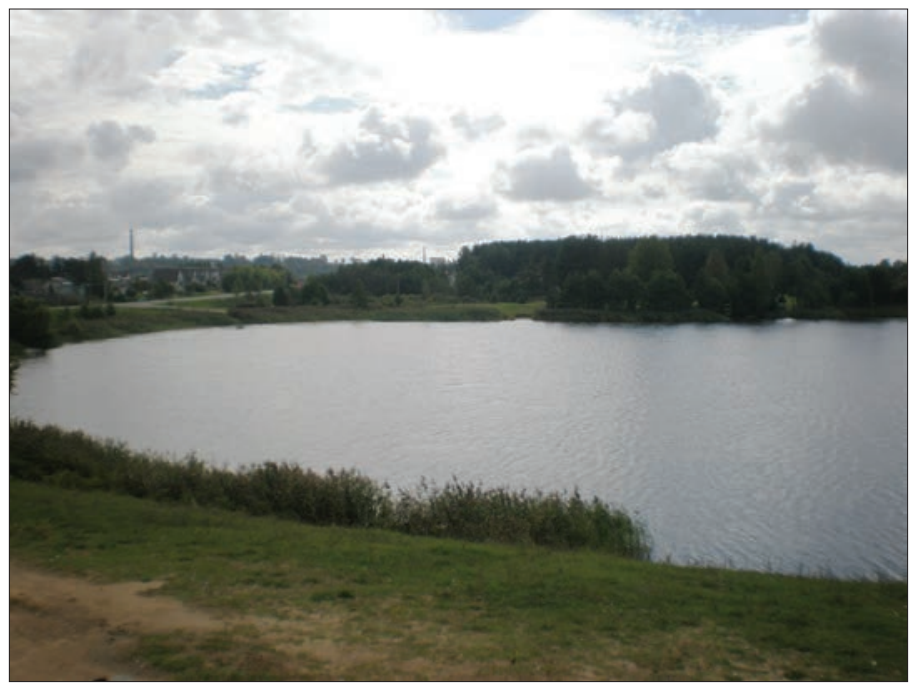

Святое озеро возле г. Лепель Витебской обл.

Фото автора, 2011 г

перспективе. В этом смысле, культурный ландшафт становится для местного сообщества «учебником истории», которая при всем своем локальном и этноцентрическом прочтении, тем не менее, органически включена в глобальную историю. При этом различные категории ландшафртных объектов описывают разные сегменты истории. Культурные элементы пространства, которые компонуют непосредственную жизненную среду человека (дом, усадьба, хозяйственные постройки), являются «иллюстративным материалом» преимущественно актуальной истории деревни во всем ее разнообразии: быт, праздники, происшествия трагические или чрезвычайные. Эпицентром конкретной деревенской истории может стать дом, храм или баня:

Была баня раз топленая. Вот мы, маладзёж, падышлі раз паглядзець. Аж там хахочуць, плёскаюць. Я адкрыла баню - аж там чәрці (Шумилинский р-н Витебской обл.) (ПЭЗ 2011: 98).

В свою очередь, локусы, которые репрезентируют сюжеты легендарной истории, как правило, размещены вне границ поселения. Существует категория ландшафтных объектов, 
которые, при своем несомненном антропогенном происхождении и фризической включенности в жизненное пространство деревни, олицетворяют в мифопоэтической картине мира идею «чужого», как в мифологическом, этнокультурном, социальном и во временном плане. Имеются в виду памятники археологии (курганы, городища), а также определенные природные объекты (озера, источники, камни) и урочища, соотнесенные в коллективной памяти с объектами культурного ландшафта: храмами, городами, деревнями, корчмами или определенными культурными персонажами.

\section{Памятники археологии}

В народной мифологии пространства курганы и городища занимают отдельное место. Это следует из их подчеркнутого отличия как от мира природы (ровная площадка, валы городища, полусферическая курганная насыпь - не имеют непосредственных природных аналогий), так и от пространства культуры. В последнем случае, граница между археологическими памятниками и «своим» миром для представителя традиционного сообщества проходит по временной шкале. Это означает, что курганы и городища, несмотря на культурный характер их происхождения, не вписываются в актуальную коллективную историю сельского сообщества, а рассматриваются только в контексте «древней» (мифологической, эпической) истории, когда жили и действовали «другие» люди, память о которых сохранилась на уровне мифологических архетипов, а не персоналий.

\section{Курган}

Во всех случаях курганы в традиционной картине мира белорусов идентифицируются как объекты антропогенного происхождения и только как места погребений, что свидетельствует как о глубине фольклорной памяти, так и о реальном эмпирическом опыте - часть курганов распахивалась и находки человеческих останков не вызывали сомнения в функциональном предназначении курганных насыпей. 
Во-вторых, курганы в народных представлениях соотносятся с идеей «чужого», которая в каждом отдельно взятом случае может иметь свое конкретное наполнение: эпохально-мифологическое (великан, богатырь - первые обитатели края, соотнесенные с мифологической эпохой; змей-портной - персонаж мифологический, агент иного мира среди людей); этнокультурное (французы, шведы, татары - «чужаки» в народной картине мира); социокультурное (топонимы «Могила Рогнеды» или «Княжеская могила» выводят на образы правителей, носителей высшей, сакрализованной власти).

Большинство фольклорных сюжетов, связанных с курганами (капцамі, валатоўкамі), имеют общую «точку пересечения»: появление захоронений подобного типа в традиционном мировоззрении белорусов соотносится с подчеркнуто кризисной ситуацией (чаще война, но и эпидемия, убийство) и, как результат, насильственной смертью. «Тал капцьь, у тых капцах людзі забітыл, гэта даўно было, бо вялікія дрэвы параслі на mыıx капиах» (Поставский р-н Витебской обл.); «Ад даўнейшых войнаў засталіся капиы» (Новогрудский р-н Гродненской обл.) (Слоўнік 1980: 404). Это обстоятельство подчеркивает оппозиционность курганных захоронений деревенскому кладбищу, которое в символическом плане предстает как поселение (село) покойников, которые умерли «своей» смертью, израсходовав всю жизненную энергию (Байбурин 1993: 101-103).

Символический статус курганных погребений в рамках локального сообщества всегда зависит от их места в системе «реального пространства», т.е. пространства, «которое очерчивается посредством чувств (были, слышали, трогали)» (Pelcowa 2005: 131), поскольку народная мифология пространства «приобретает реальное содержание только в границах определенной ландшафртной структуры» (Панченко 1998: 14). Таким образом, для мифологической интерпретации курганов важное значение имеют их конкретные пространственные характеристики: площадь (количество), размеры, местонахождение (в лесу, на поле или на деревенском кладбище).

Для традиционной картины мира знаковыми являлись необычные (большие) размеры курганов, что при соотнесении с параметрами «нормальных» («своих») могил, в которых похоронены родственники и соседи, формировало устойчивое представление о необычных фризических характеристиках людей, погребенных 
под курганными насыпями. В значительной степени это коррелирует с мифологическими представлениями о великанах, которые жили во времена сотворения мира.

Казали, на той гори, де контора, е курганы. Було тут село и була война, и людей богато набили и позагребывали. Казали, шо копали да вукопали таку голлёнку, костку - буто з человека, як дитя годоў $з$ десять. Такие були люди великие колись (Лельчицкий р-н Гомельской обл.)

Косци находили. Дзе даўнейшыя могилки. Великаны були (Ивацевичский р-н Брестской обл.) (Белова, Петрухин 2008: 99-100).

Большой одиночный курган в фольклоре может выступать в качестве своеобразного "центра», вокруг которого создается поселение, разворачивается собственно культурное пространство. Например, большой курган фигурирует в преданиях об основании Могилёва (погребение легендарного разбойника Машеки - курган «Могила Льва» - становится эпицентром города и дает ему название) и Телеханов: «Тут была... когда-то могила хана. Был большой курган. Возле него селились люди» (Легенды 2005: 287, 331). Курганы этой категории соотносятся с персоналиями легендарной истории, а размеры курганных насыпей в народном сознании соответствуют социокультурному статусу погребенного там человека (князя, военачальника).

На Калавурскай гарэ была бальшая валатоўка. Казала пра гэта маці.., што валатоўку гэту насыпалі даўным даўно салдаты. На гарэ яны сталі аддахнуць. Генерал іхні загадаў насыпаць валатоўку аб сабе на памяць (Лепельский р-н Витебской обл.) (ПЭЗ 2011: 273).

В отличие от одиночных курганов, группы курганных насыпей в традиционной картине мира воспринимались как захоронения коллективные (массовые) и при этом синхронные, что могло быть результатом лишь одноактового трагического события (война, битва) с обязательным участием «чужаков» (французов, шведов, татаров). Типологическая тождественность всех насыпей в пределах курганной группы лежит в основе народных представлений об абсолютной этнической и социокультурной идентичности захороненных там людей. В традиционной картине мира предствителями однородной социальной группы, которые единовременно погибли в результате каких-либо 


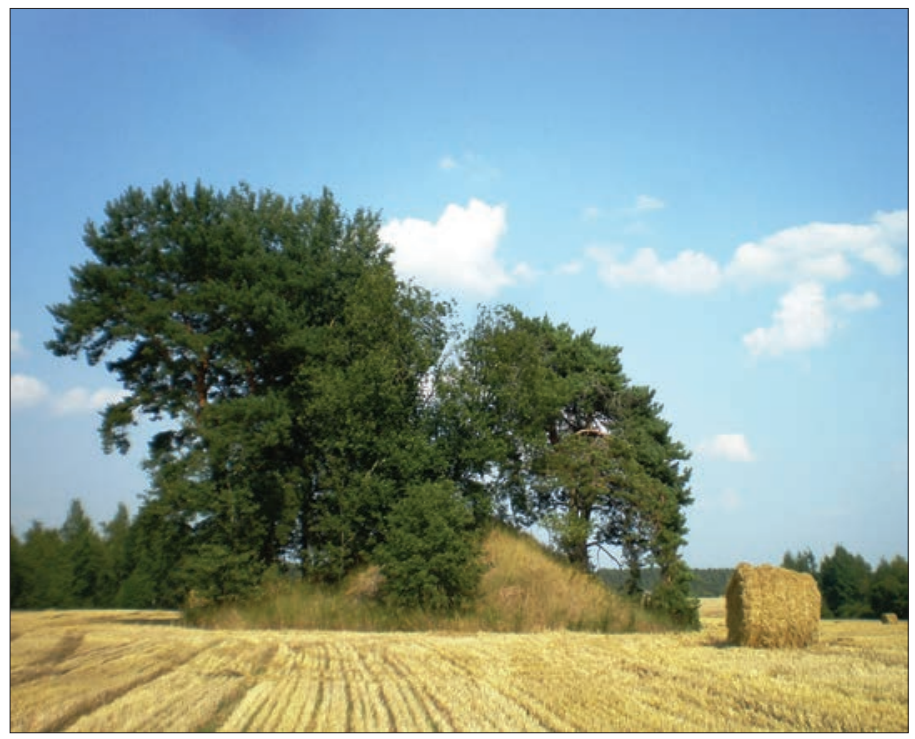

Большой одиночный курган возле д. Гомля Полоцкого р-на Витебской обл. Фото автора, 2015 г.

драматических событий, могли быть солдаты. «В этой местности... встречаются, и даже очень значительные, насыпанные курганы. О них сохранилось в народе предание, что курганы эти насыпаны на могилах убитых воинов» (Легенды 2005: 259).

Закономерной представляется и частотность этнических наименований в народных названиях курганов (французские, шведские, татарские), а также их ареальная локализация. Во всех случаях фольклорная (коллективная) память фиксирует наиболее масштабное и знаковое для конкретного региона военное нашествие «чужаков». Для населения Северной Беларуси, где события Войны 1812 г. носили ожесточенный характер, объектом фольклоризации стала армия Наполеона. «Французские могилы» в народных предоставлениях фригурируют как места массовых захоронений солдат наполеоновской армии. «Як фбраниузы ішлі, іх тут убівалі, закапавалі іх тут убітьх - эта валатоўкі» (Лепельский р-н) (ПЭЗ 2011: 265). 


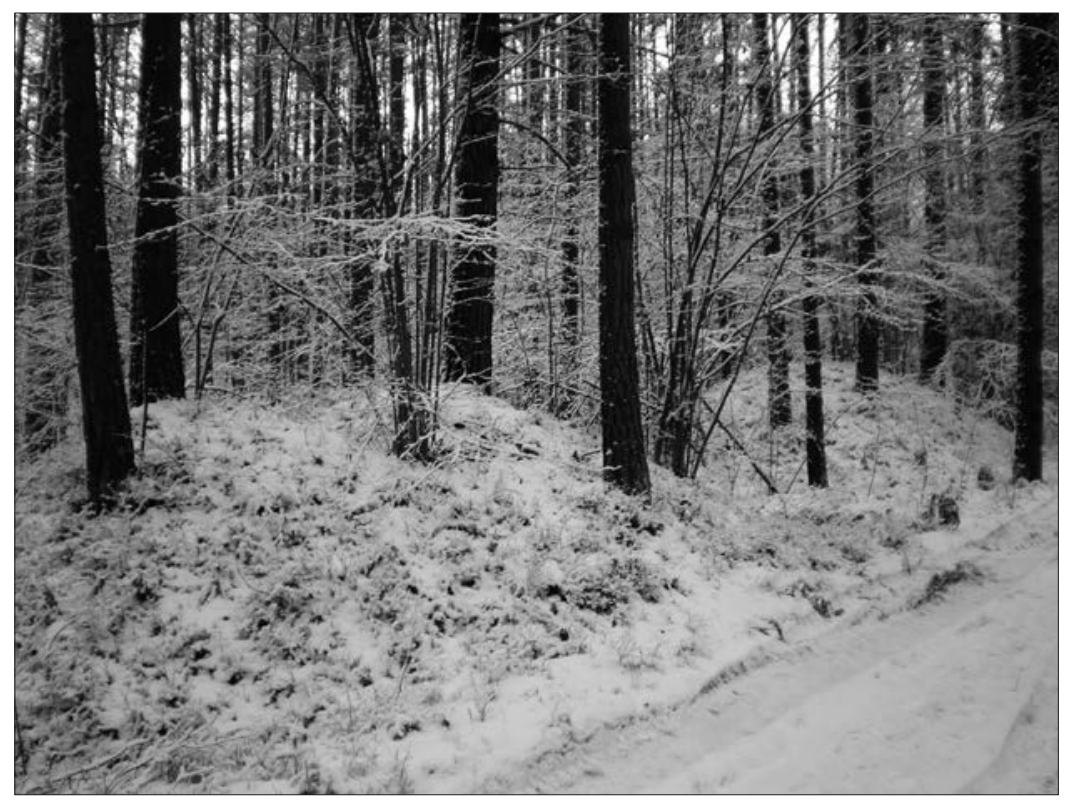

«Французские могилы» (Курганы Х-XI вв.) возле д. Углы Полоцкого р-на Витебской обл. Фото автора, 2008 г.

В ряде случаев в качестве «братских могил» солдат французской армии выступают городища железного века, известные у местного населения под характерным названием «Французская гора».

Вот у Шалцінах, возле озера, гара называецца Французская, патаму шта там захараненіе французскіх салдат 812-га года. I па сей час іх можна там адкапаць, косці яшчо сахраніўшыся (Миорский р-н Витебской обл.) (ПЭЗ 2011: 249).

Показательной в контексте противоречивого характера Войны 1812 г. для Беларуси является фольклорная персонализация военных событий. Довольно часто в исторических (топонимических) преданиях фригурирует Наполеон, но полностью отсутствуют российские персоналии: император Александр, фрельдмаршал Кутузов, генерал Витгенштейн (который активно действовал как раз на территории Беларуси). Французский император в фольклорной истории очень часто выступает как 
воплощение всей своей армии. "Курганы - гэта тали шоў $\mathrm{Ha}$ палеон»; «Гаварылі, што кагда Напалеон ухадзіў, вот эта тал захараняліся людзі, і вродзе бы такія курганы тал» (Борисовский р-н Минской обл.) (ПЭЗ 2011: 275-276).

Для населения Западной (Северо-Западной), Центральной Беларуси и, частично, Полесья объектам фольклорной мемориализации стала Северная война (1700-1721) и шведская армия Карла XII, которая была известна своей жестокостью именно в этих регионах. Как и в случаес с Войной 1812 г., механизмом объективации исторической памяти о событиях Северной войны выступают курганные насыпи и соответствующие предоставления. «Талака горы ёсиь, вунь тудьь. Шведь ваявалі тут. Наверна. Вот яны сваіх байцоу харанілі, такія горы дзелалі» (Докшицкий р-н Витебской обл.) (ПЭЗ 2011: 270).

В юго-восточных районах Беларуси актуальным сюжетом фольклорной истории являются набеги крымских татар. Объективация памяти о чужеземном нашествии в данном случае также реализована посредством интерпретации курганов и других археологических памятников, что отображено в топонимии. «На территории Беларуси довольно многочисленны микротопонимы Татарская Гора, Татарские Могилы, Татарские Моглицы» (Дучыц 1993: 26).

Память о татарских набегах оказалась чрезвычайно устойчивой, поскольку татары стали в традиционной картине мира белорусов концентрированным воплощением «чужака» по всем параметрам этнокультурной идентификации (антропологический тип, язык, религия, одежда, быт, «нечеловеческое поведение» и др.). «О тех курганах рассказывают: татары напали на этот край и произвели страшное опустошение: жгли сёла, грабили церкви, издевались над женщинами, детьми и стариками. [...] На другом берегу реки стоял ещё один большой отряд татаров. Бог послал им слепоту, наказав за зверства... Не узнав своих и подумав, что это русины, начали уничтожать один одного до последнего. От них и произошли курганы» (Легенды 2005: 241).

В регионах, которые испытали на себе нашествия многих вражеских армий, может происходить своеобразная миксация различных пластов фольклорной истории, когда образы чужаков смешиваются и выступают как единое целое. 
Ёсць жа вон там горкі... Но, казалі, што ішоў жа гэты турак, швэд, Напалеон гәты, ну і дужа людзей пабілі многа, водзека і сыпалі (Докшицкий р-н) (ПЭЗ 2011: 269-270).

Фольклорные «комментарии» относительно безусловно исторических, с точки зрения местной традиции, объектов (курганов, «шведских» или «французских могил»), как правило, очень краткие и имеют характер констатации (кто и в итоге чего погребен), в которой даже не находится места для обозначения противников погибших солдат. Такой же минимализм свойственен и представлениям, в которых фигурируют исторические личности - Карл XII или Наполеон. Информация о личных характеристиках этих персон (физиометрические данные, характер, внешний вид и т.д.) отсутствует, а все повествование сводится к обозначению конкретного действия («обедал», «отдыхал») в соотнесении с конкретным локусом (камень, гора, урочище). Минимализм и выборочная конкретика народно-исторических нарративов является логичной, исходя из закономерностей функционирования эпического фольклора. Как отмечал В. Я. Пропп, «в фольклоре рассказ ведется только ради повествования о том, что происходит. Эта исключительная динамичность действия приводит к тому, что в повествовании фигурируют только те лица, которые будут играть свою роль в развитии действия» (Пропп 1976: 91).

Частотность «военной тематики» в топонимических преданиях обусловлена спецификой белоруской истории, когда страна очень часто оказывалась на пути захватчиков разного рода. $\mathrm{C}$ другой стороны, немаловажной является и символическая интерпретация войны в мифопоэтической картине мира. Война, несмотря на свой деструктивный характер, как и любое событие экстраординарного, переломного (переходного) характера, выявляет свои созидательные потенции. После войны традиционный культурный ландшафрт пополняется новыми элементами. И не только местами захоронений, но поселениями и даже культовыми объектами. «Другой пласт "военно-исторического” фольклора представляют нам местные топонимические предания, в каких воинственные противники часто выступают в роли культурных героев» (Белова \& Петрухин 2008: 103).

Согласно фольклорной традиции, целый ряд ойконимов появляется и имеет свое объяснение именно в контексте военных 
событий. В то же время, по логике мифологического мышления, придание имени (названия) объекту является тождественным созданию самого объекта и включению его в пространство культуры. Возникновение новых поселений связывается фольклорной историей практически со всеми знаковыми для территории Беларуси захватчиками: татарами, шведами, фрранцузами. Так, происхождение деревни Мамаи и её названия (Глубокский р-н) местное население соотносит с нашествием татар и их предводителем ханом Мамаем: «Это было в двенадцатом веке. [...] Было тут нашествие татар. И там не было ничего, только был лес и был лужок. И татарский хан Мамай поставил палатку на лугу, и дали название Мамаи» (Легенды 2005: 314).

Абсолютно «прозрачным» для фрольклорного сознания является название деревни Швяды: «А тал Швядьь. А Швядь называециа, што ў мірнае врэля кагда-то войска стаяла шведскае» (Вилейский р-н Минской обл.) (ТМКБ 2011: 464). Появление значительного количества поселений соотносится коллективной памятью с Войной 1812 г. «Рассказывают, что раньше эта деревня называлась Наполеоновка. Но произносить такое долгое название было неудобно, вот и переделали его в Паленовку» (Лиозненский р-н) (Легенды 2005: 318). В случае с деревней Париж (Поставский р-н Витебской обл.), для народной версии происхождения названия военный контекст легендарного события вообще не является значимым, поскольку акцентируется красота и неповторимость локального культурного ландшафта, которые в глазах фрранцузского императора якобы и становятся причиной для знакового наименования.

Ну, гәта ж тады гаварылася, што тут ішоў Напалеон і быў астанавіўшыся вот на гэтым пагорачку. I тады пайшло тады, што Парыж гәты, што выйшаў і сказаў: Красіва, як у Парыжы... ${ }^{1}$.

Нашествие воинственных иноземцев приводит не только к образованию новых поселений, но в ряде случаев пополняет местный культурный ландшафт сакральными объектами с культовым статусом. В Слонимском районе Гродненской области «авторство» известного храма в д. Сынковичи приписывается фольклорной традицией шведам, которые построили ее среди непроходимого леса (ТМКБ 2006: 413). В Докшицком районе Витебской области известен культовый Шведский колодец: 


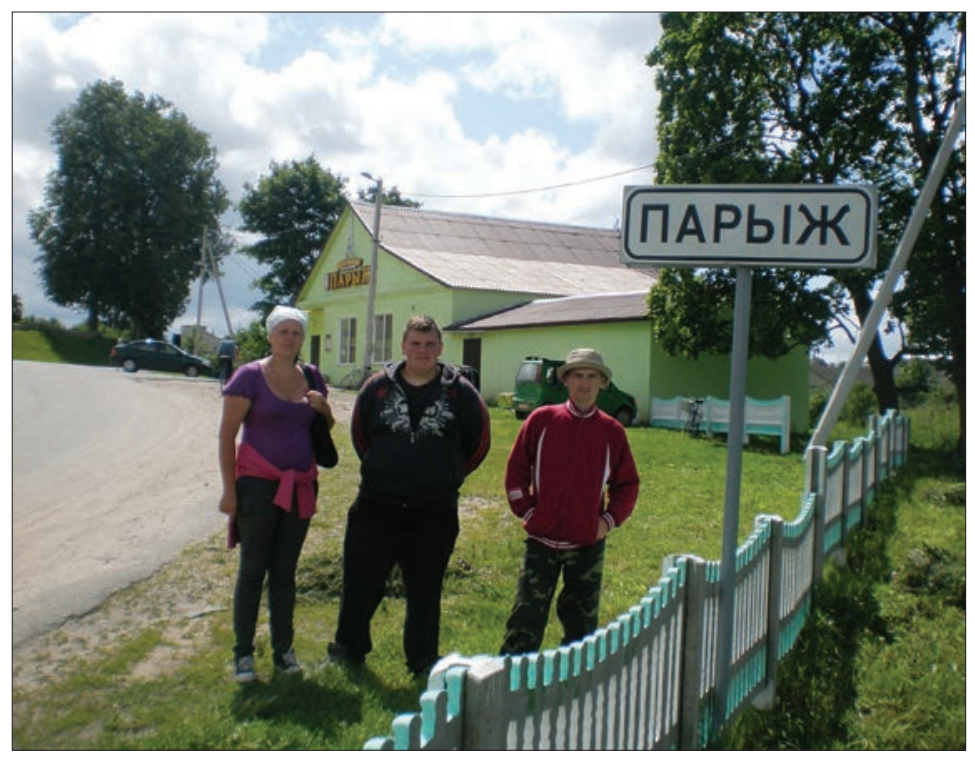

Участники этнографической экспедиции Полоцкого университета в деревне Париж Поставского р-на Витебской обл, якобы получившей свое название благодаря императору Наполеону. Фото автора, 2014 г.

Тут недалёка стаіць Шведскі калодзеж. Гаварылі, што калі ішлі шведы, надта ім захацелася піць, а вады не было. Камандзір загадаў па адной шапцы кожнаму зачарпнуць, спусціцца з гары - і будзе вада. I яны ўсе па шапцы як зачарэпнулі, і пайшла рэчачка адтуль (ПЭЗ 2011: 206-207).

Сопоставление и анализ топонимических преданий относительно курганов дают ценный материал для уточнения временного лага актуальности тех или иных исторических событий в фольклорной картине мира. В 1907 г. этнографр К. Аникиевич, описывая исторический ландшафт Сенненского уезда Могилевской губернии, отметил, что в народном восприятии курганы чаще всего фригурируют как «шведские могилы» и лишь изредка как «французские» (Аникиевич 1907: 61). Однако, уже в 1970-80-х гг. археологические исследования на территории бывшего Сенненского уезда показали, что среди народных названий курганов однозначно преобладают «французские могилы», а «шведские» не фриксируются вообще (Збор 1985: 398-408). 
Вместе с тем, полевые этнографические исследования начала XXI в., проведенные в Северной Беларуси, выявили и новый пласт исторических реалий, соотнесенных в фольклорной памяти с курганами: погребения начинают отождествлятся местным населением с событиями I Мировой (“Николаевской”) войны, в то время как память о 1812 г. постепенно вытесняется.

На Амяньку сугробы высокія. Мой бацька Агей Рыкун, а бацьку дзед - Сямён Рыгоравіч - расказваў, калі была Мікалаеўская вайна, то хавалі бітых у тых сугробах (Лепельский р-н)

Каля Крумплева, калі ідзеш туды к Дзвіне, сопкі там. Як капна, такія круглыя. Можа тры, можа сколькі... Гэта, як укрыцьце, вродзі бы, старай Мікалаеўскай вайны (Полоцкий р-н Витебской обл.) (ПЭЗ 2011: 269, 274-275).

Таким образом, хронологическая дистанция между историческими событиями, которые были фольклорным образом объективированы курганными насыпями, составляет приблизительно 100 лет (Северная война на территории Беларуси 1708-1709 гг./ Война 1812 г. / I Мировая война 1914-1918 гг.). Этот временной лаг, который в среднем соответствует жизни 3-4 поколений, и может рассматриваться как хронологический промежуток, в рамках которого и происходит фольклорная интерпретация реального исторического события и его объективация в виде определенных элементов культурного ландшафта. За пределами этого срока ландшафтная «иллюстрация» местной истории может изменить свою легенду на более актуальную с точки зрения представителей локального сообщества.

Можно констатировать, что в основе фольклоризации исторических событий и, соответственно, вариативных народных названий курганов лежит одинаковый принцип. «Предания о войне и интервентах без колебаний можно квалифицировать как однородное семантическое поле. Его «общий знаменатель» составляют представления о войне и солдатах как о чем-то чуждом, внеположенном деревенскому миру» (Платонов 1998: 223). При этом, устойчивое соотнесение курганных захоронений с войной в народном сознании довольно знаково материализовалось во второй половине XX в., когда только в период с 1964 по 1971 г. на территории Беларуси было насыпано 95 величественных «Курганов Славы» (Барысевіч 1972: 212-215). Естественно, что в данном случае мемориальные комплексы были посвящены 
не «чужеземцам», но соотечественникам, которые погибли на фрронтах II Мировой войны, солдатам, освобождавшим страну от нацистских оккупантов. Но при этом, мифологический принцип фиксации и объективации истории посредством топографического объекта остался неизменным.

\section{Городище}

В традиционной картине мира белорусов городище имеет отчетливый медиативный статус и соотносится с «чужаками» в социокультурном либо этническом плане. Самые распространенные в народе названия городищ - Городок, Городец, Городище (Дучыц 1993: 7) - в этимологическом плане смыкаются со словом «город» (др.-слав. градъ, сравни лит. gařdas 'ограда', др.-инд. grhás 'дом’) и означает огражденное поселение.

Все фольклорные сюжеты, связанные с городищами, разворачиваются в плане исторической перспективы и апеллируют к мифологическим первопоселенцам края или же к теме войны с чужеземцами. Наиболее архаичными, по нашему мнению, являются легенды и предания первого плана. Как отмечал К. Аникиевич в начале XX в., «происхождение «городков» народ объясняет также, как и курганов, - в городках жили “асилки” (может быть старейшины, первые князья), которые воевали друг с другом каменными топорами» (Аникиевич 1907: 64).

Развернутое и знаковое в деталях предание о происхождении городищ записал у белорусов Себежского уезда Ф. Альхимович.

Вот і задумалі яны (асилки - В. Л.) тутацька абсяліцца і пачалі зразу строіць два гарадзішчы - Забыркі і Іваніху. Народу тут было многа, шутка сказаць, кажынны год бабы прывадзілі па два ды па тры рабёнкі. Струменту ў іх пашці ніякага не было. Кажуць, што ў іх быў на ўсіх адзін тапор, да і той не жалезны, а якісь медзяны, а, можа, і жалезны, пра гәта дзяды не сказывалі настаяшча, мусіць, запомнілі. Адно звесна, што асілкі не мелі струменту, а гарадзішчы строілі. [...] Яны і звярәй убівалі камнямі, адтаго камні і ляжаць аж да сягоння па лясу. А далі ... асілкі ўшлі адсюль, як толькі перавяліся ў лясах звяры і пазменшала рыбы ўвадзе, бо ім не з чаго стала жыць. 3 тых пор і гарадзішчы іхнія запусцелі, бо послі іх не скора прыйшлі сюды нашы дзяды, каторыя абабралі сабе другія мясціны, каторыя больш спасобны для хлебапашаства і для разводу скацінкі (Легенды 2005: 45). 


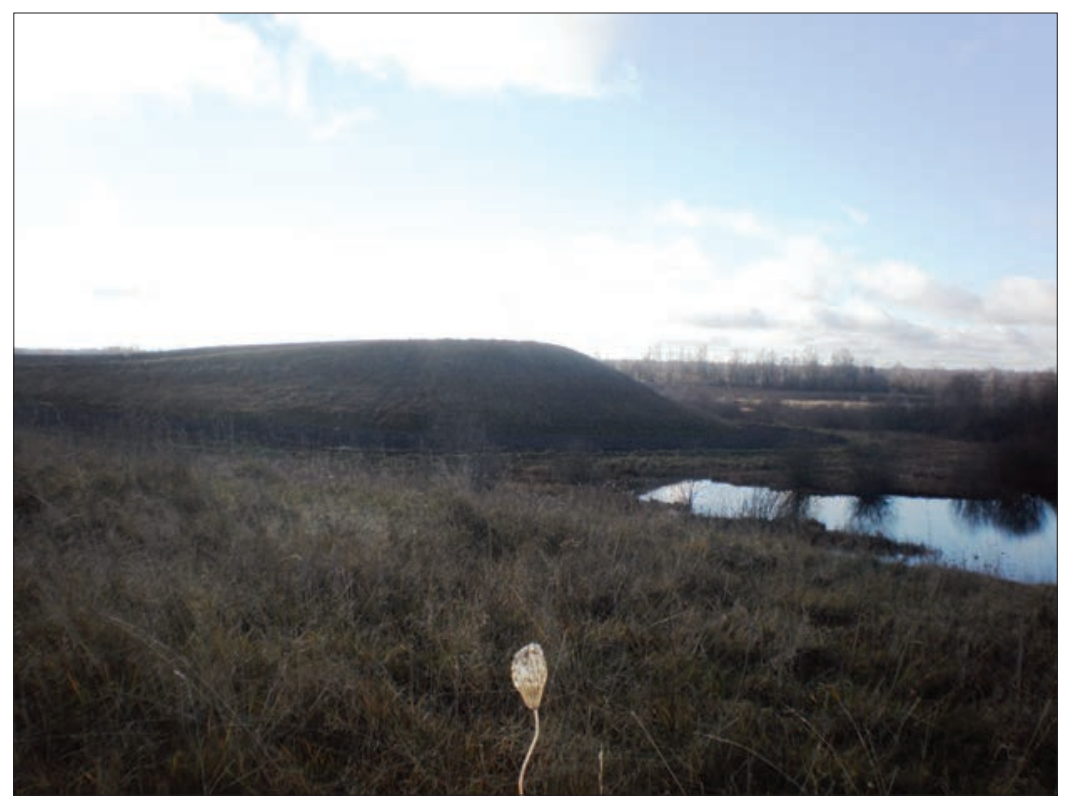

Городище железного века возле д. Катушенки Полоцкого р-на Витебской обл. Фото автора, 2010 г.

В приведенном предании показательно то, что городища выступают как исскуственно созданные поселения, жители которых принципиально отличаются от белорусских крестьян не только физиометрическими данными, но и хозяйственным укладом (охота, рыболовство и собирательство, противопоставленные земледелию).

В белорусской фольклорной традиции городище может соотноситься лишь с одним мифическим жителем, который, соотносительно с размерами своей «усадьбы», имеет характеристики великана или богатыря. О городище железного века, расположенном на острове Освейского озера (Верхнедвинский район Витебской обл.) сохранилось следующее предание:

У Асвее, на остраве ёсць гара Гарадок, а недалёка ад Асвеі, ёсць Дароціна гара [растояние между объектами около 4 км. В. Л.]. Раней на Дароцінай гары жыла чараўніца Дарота, а на Гарадку - княгіня-чараўніца. На Іванаву ноч яны перакідаваліся палкамі ${ }^{2}$. 
В Северной Беларуси предания о девах-воительницах, живущих на городище (горе), связаны с «Багатыр-гарой» (Россонский р-н), горой Княгиня (Ольгиной горой) и Доротиной горой (Верхнедвинский $\mathrm{p}-\mathrm{H})$.

У якую-та вайну там, на гары, ваявала княгіня Вольга, а яе салдаты на гару [зямлю] шапкамі нанасілі.

Ну, як во я ад старых чула: што была такая Дарота - ваявала 3 гәтай гары... I тая Дарота, ну, не то што кідала, страляла, можа з лукаў яшчэ тады. Ну, наверна сільная жэншчына была, раз ваявала. Ну, гэта даўно (было) (ПЭЗ 2011: 248-249).

Типологически схожее предание бытует и о Марьиной горе в Чашникском районе Витебской обл.:

Ну, там, гавораць, што як з французамі ваявала тая Мар'я, дык яны (французы) пілоткамі нанасілі гэту гару. Там роў такі ёсць кругом гары, там манеты старыя находзюць. Там тая Мар'я ваявала з французамі. Яна памешчыцай была, там у яе усадзьба была. Вродзе бы, гаворуць, яна там дзеньгі схувала, і ніхто не знаіць дзе ${ }^{3}$.

С городищами как местами проживания предыдущих поколений людей связан пласт преданий о поселении (городе, селе, храме), которое провалилось под землю. «Недалеко от нас есть большая гора Городище. Было там когда-то местечко. В этом местечке был костел. Из этого местечка выходила замуж девушка. Мать не хотела отдавать ее замуж. Когда выезжали венчаться, мать прокляла дочку и сказала ей: «Чтобы оттуда не вернулась, чтобы ты там утонула». И костел, и местечко утонули» (Ошмянский р-н); «Возвышенность возле деревни Новое Прибужье... называется Городок. О нем рассказывают, что тут была гора, которая раскрылась и поглотила небольшое селение с церковью» (Чаусский уезд) (Легенды 2005: 351-352).

Другая группа преданий о городищах связана с темой войны с интервентами, о чем и свидетельствуют народные названия археологических памятников: Татарская, Турецкая, Французская, Шведская гора (Дучыц 1993: 44). Городище может фигурировать и как укрепление, и как погребение, но во всех случаях насыпанное вражескими солдатами мифологическим способом (сапогами, шапками, касками). 
Наступленне было шведаў на Расію, гәта ж даўным-даўно легенда ідзець. Ну, дзета тут ўбілі іхняга палкаводца. Яго палажылі, пахаранілі вунь тут во, сколька войска было - каждый у шапкі наняслі. Каскамі чәрпалі пясок, няслі і сыпалі. У чэсць гәтага палкаводца насыпана гара і называюць таму Швецкая (Докшицкий район)

Па разгаворам, сначала как салдаты нанасілі гэту гару каскамі. А Бог іх знаіць, хто такія, многа наверна. Гэта історыя першабытная. I там царковачка была, служба, када людзі хадзілі (Россонский р-н) (ПЭЗ 2011: 250, 252-253).

В структуре локальных культурных ландшафров с курганами и городищами довольно часто соотносятся объекты сакральной географии («деревенские святыни»): святые камни, источники, колодџы. В середине XIX в. крестьянами Себежского уезда особо почитался культовый камень Пястун, расположенный вблизи курганов, которому приносили дары в виде денег, полотна, поясов (Анимеле 1854: 267). На периферии курганных групп или в непосредственной близости от них находиться значительное количество культовых источников Белорусского Подвинья, почитаемых местным населением за целительные свойства воды (Лобач 2013: 459). Схожая топография культовых объектов и археологических памятников характерна и для территории соседней Псковщины (Штырков 2003: 37).

Вероятно, что наличие погребальных памятников вблизи культовых объектов сакральной географии может быть объяснено исходя из архаического представления о том, что древние могилы связаны не только с миром умерших, но и с сакральной сферой миропорядка в целом. Иной мир в мифологических представлениях рассматривается как вместилище необычных, сверхъестественных ресурсов и потенций (пророческие знаки, чудесное выздоровление или нежданное богатство человек получает именно оттуда). Не случайно, как отметил А. Панченко, крестьянами «древний курган или жальник нередко воспринимается как источник «святости» (Панченко 1998: 261).

Сквозной сюжетной линией, которая характерна для большинства топонимических преданий о нашествии интервентов, являются рассказы о кладах и богатствах, спрятанных вражескими войсками в курганах и городищах. «О былом нашествии «чужих» народов напоминают не только ископаемые останки и различные сооружения, но и такой обязательный элемент 


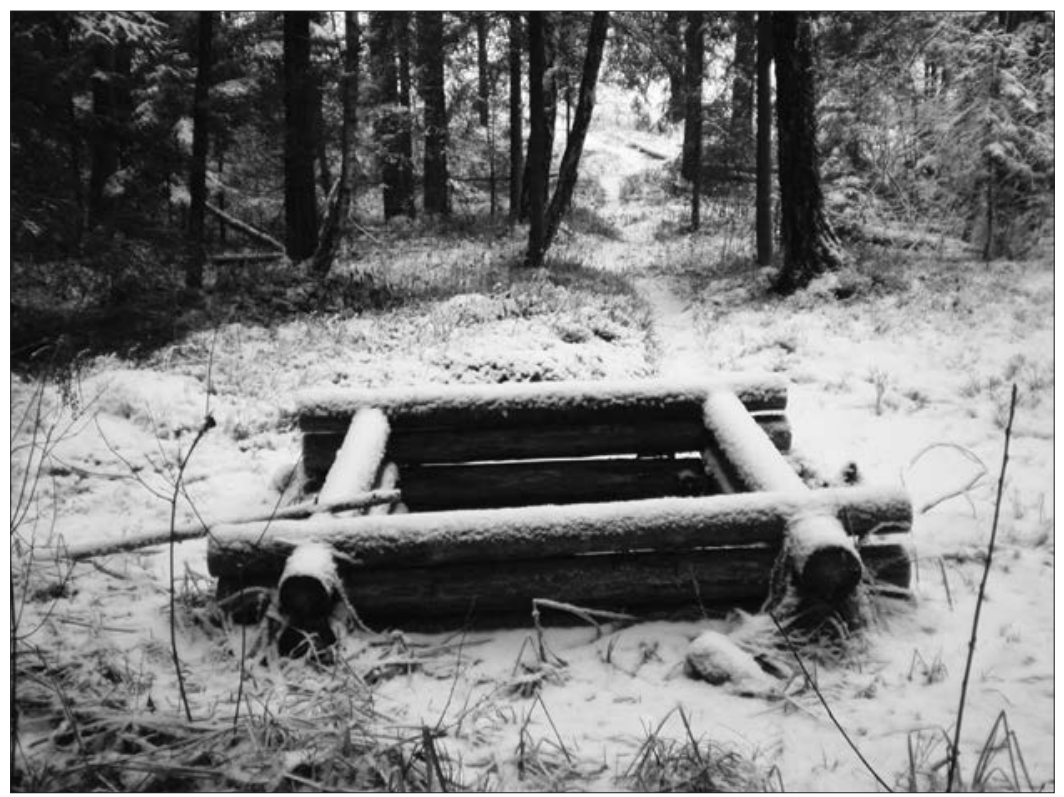

Культовый источник Святуха, расположенный на переферии курганного могильника X-XII вв. возле д. Углы Полоцкого р-на Витебской обл. Фото автора, 2008 г.

«историко-географического фольклора», как оставленные пришельцами клады и сокровища» (Белова, Петрухин 2008: 107).

С учетом исторических реалий (армия Наполеона захватила и разграбила Москву, после чего вынуждена была панически отступать), безусловное первенство по количеству «спрятанных кладов» на территории Беларуси принадлежит фрранцузам. Предания о кладах Наполеона известны практически в каждом районе, где в свое время проходила французская армия. Нарративы такого рода фриксируются в Борисовском, Вилейском, Докшицком, Полоцком, Россонском, Сенненском, Ушачском и других районах Беларуси. Объектами, где «чужаки» спрятали свои ценности, выступают курганы и городища.

Вот тожа легенда - Залатыя горы. Там пагоркі небальшыя, да нет, можа з хату не будзець... Там нескалькі пагоркаў. Гавораць, што там закапана фрранцузамі золата (Полоцкий р-н) (ПЭЗ 2011: 247). 
Хозяевами легендарных кладов в белорусском фольклоре выступают и шведы, которые могли прятать богатства не только в курганах, но и в городищах. Однако овладеть сокровищами сможет лишь тот, кто исполнит немыслимые условия - успеет съездить в Вильно (Вильнюс) на трехлетнем бычке и вернуться оттуда за три часа.

А во Шведава гара! Шведамі яна насыпана. Када ішла вайна, ішоў швед, і кажды, гавараць, ну шлём, па шапцы насыпалі і гару насыпалі. Тут убіты глаўны іхны. I ён умураваны сярод гары гәтай. І тут жа дзе-то ёсць і вароты. Дзверы, да. Ёсць. Але ніхто не знаіць. Дзверы на васток. Тут какая-та пасловіца дзедава: бочку золата (дастанеш), еслі на бычку, на трэцячку з'едзеш у Вільна за тры часы, і прыедзеш. Золата тады (Докшицкий р-н) (ПЭЗ 2011: 250).

В фольклоре Восточного Полесья сокрытие кладов приписывается туркам, татарам, но чаще - козакам, что является воспоминанием о событиях «казацкой войны» 1649-1651 гг. Как заметил Ч. Пяткевич, «в понимании полешука все курганы от времен битвы с козаками... в окрестностях Хойников, Загалья, над рекой Витей, а также Лоева и Хэлмеча, имеют клады» (Пяткевіч 2004: 480). В легендарном «колодце Тура», который в предании фригурирует как центр образования города Турова, якобы спрятано турецкое золото. «Говорят, в колодце турецкая шапка лежит золотая» (Житковичский р-н) (Белова \& Петрухин 2008: 108).

Деньги (золото) как материальная квинтэссенция богатства в народной традиции устойчиво соотносятся со сферой «чужого» и ее представителями. «Зарывают клад разбойники, «паны», интервенты, аборигены края.., т. е. персонажи, обладающие «инобытийным», «внешним» статусом и особой магической силой» (Панченко 1998: 227). Отсюда, весьма распространенная традиция сельского кладоискательства имела целью не столько «обогащение в современном смысле слова, но обретение магической удачи, коммуникацию с сакральным миром, изменение прирожденной «доли» (Панченко 1998: 228). Полевые этнографические исследования показывают, что практически все поколения деревенского мужского населения в подростковом возрасте искали «богатую долю», производя самодеятельные раскопки на городищах и курганных могильниках (Лобач 2014: 30-35). 
На полі валатоўкі фрранцузскія. Гэта з французскай вайны. Там рабяты дзелалі раскопкі. Ну, капаюць, а там нічога нету (Лепельский р-н) (ПЭЗ 2011: 275).

\section{Исторические личности в топонимических преданиях}

Феномен войны хотя и является существенно важным для истории фольклорного типа, но выступает далеко не единственным историческим пластом, отраженным в коллективной памяти и объективированным посредством элементов культурного ландшафрта. Значительное место в исторической топографии занимают локусы, соотнесенные «местной историей» с деятельностью монарших особ, которые в традиционной картине мира очень часто наделяются чертами культурных героев. С ними связывается появление новых элементов культурного ландшафрта: поселений, дорог, культовых объектов. В Южной и Западной Беларуси креативные функции приписываются королеве Боне Сфорца (жене великого князя литовского и короля польского Сигизмунда I Августа), в северо-восточной части страны наиболее распространенным фольклорным образом «преобразовательницы» является российская императрица Екатерина II. Такие региональные отличия объясняться историческими реалиями: большинство владений Боны Сфорцы находилось на территории современных Брестчины, Гомельщины и Гродненщины, а северные и восточные районы (правобережье Двины и левобережье Днепра) были присоединены к Российской империи времен правления Екатерины II значительно раньше, чем остальные регионы Беларуси (II раздел Речи Посполитой произошел в 1772 г.).

Созидательная деятельность исторических персонажей, что выявляется в основании (наименовании) новых поселений или других топонимических реалий, реализуется в процессе путешествия. "Ехала иарыца Кацярына праз нашы месиы. Так тут красіва было. Панравілася ёй. Едзе і гаворыць: "Пьишна, пьц- на!" За тое і наша вёска стала называциа Пьшна. А як у Лепель прыехала, а тал ... яшчэ красівей. Так тады: “A mym і лепей”. Om i пайшло: Лепель» (Легенды 2005: 283). 
С российской императрицей фольклорная традиция связывает и культурогенез острова на Освейском озере:

Ну, такая пра остраў ёсьць легенда. Што Кацярына первая саслала трох людзей на остраў: Бірулю, Ваську і Лася. Ix пераправілі на плоце. Яны пастроілі хату і разрабатывалі тры часьці острава. А между работай насыпалі шапкамі курган - Гарадзец. Во, па іх іменах і названія: Бірулін рог, Васькава, Лоськава (Верхнедвинский р-н) (ПЭЗ 2011: 259).

Схожие креативные функции народная традиция приписывает и королеве Боне: «Местность, где теперь находятся Крынки, была покрыта лесом, в котором было много источников и ручьев... В 1500 году тут проезжала... королева Бона. Она тут застряла в роднике. Вышла она... со своей тачанки на возвышенность и приказала построить на этом месте поселение. Была построена и церковь...» (Легенды 2005: 308).

Довольно часто с образом Боны Сфорцы связывают городища и замчища. «В Беларуси распространено предание о том, как на месте городища или замчища в старину стоял дворец королевы Боны. Об этом рассказывают в Мяделе, Кричеве, Пинске, Радошковичах, в окрестностях местечек Волпа и Мсцибово Волковысского, Селец Березовского р-на, около ДавидГородка... Согласно одним представлениям, королева в замке просто жила, согласно другим - она... замок построила» (Дучыц \& Клімковіч 2011: 312).

В числе иных исторических персоналий высшего ранга в топонимических преданиях фригурируют великий князь литовский Витовт, король польский Стефан Баторий, а также российский монарх Петр I, шведский король Карл XII и Наполеон. Указанные персонажи, как правило, «прочитываются» местной традицией в контексте военных событий. «Возведение некоторых городищ приписывается Петру I. Городище в Индуре около Гродно, согласно одному из преданий, насыпано Петром Великим во время войны со шведами. А на городище Замочек в д. Ивань Слуцкого р-на вроде бы стоял лагерь Петра I» (Дучыц \& Клімковіч 2011: 312). В Верхнедвинском районе известна «Батурава Гара», где король не просто воевал, но якобы погиб и был похоронен.

А нідалёка ат таго места, дзе калі-то была Росіца, ёсць ішчэ места - Батурава Гара. Даўней гаварылі, што на тым месці пагіб і пахаронен ні то цар, ні то бальшой палкаводзіц Батура ${ }^{4}$. 
Схожую закономерность можно заметить и применительно к преданиям о Витовте, правление которого было отмечено активной внешней политикой и большим количеством военных походов.

На севере и в центре Беларуси еще и сегодня некоторые дороги и старые гати через болото называются Bimaўmaвылмі. На Глубоччине в районе местечка Псуя выложенная бревнами дорога, согласно преданию, была построена литовским князем Витовтом. Вітаўтава Дарога имеется и к востоку от Крупок, а Вітаўтавы Шляхі - около деревни Валадута на Червенщине и около дд. Вороничи и Заскорки на Полотчине (Дучыц $\&$ Клімковіч 2011: 309-310).

Таким образом, знаковые исторические персонажи, которые наиболее часто фигурируют в коллективной памяти и соотнесены в фольклорной истории с конкретными элементами локального культурного ландшафрта (курганами, городищами, камнями, источниками и т.д.), выступают в качества маркеров, своеобразного отображения наиболее знаковых исторических событий не только местной, но и общеэтнической истории.

\section{«Народная библия» и культурный ландшафт}

Важнейшим пластом в памяти фольклорного типа является библейская история в ее местной интерпретации и в проекции на реалии локального культурного ландшафта. «Легенды и предания, в которых речь идет об «истории» и ее видимых последствиях (местные топонимы, природные объекты) в определенной локальной традиции, только отчасти можно считать «топонимическими», поскольку в них, помимо фиксации и объяснения местного топонима или природной реалии, большую роль играют мотивы, значимые для этиологических рассказов «народной Библии» (Белова \& Петрухин 2008: 7).

В ряде случаев происходит «перенос» библейских топосов на полотно локального культурного ландшафра. Таким примером может быть культовый источник Русалім, известный в Сенненском районе.

Он быў небальшы, дзеравянны зруб. Я ў бацькі свайго спрашывала, чаго тут калодзесь. А ён гаворыць: эта калодзеж святой. 
Русалім называецца... Гаварылі, што святы калодзеж. Ішлі 3 цәркві кросным ходам, па этай цежкі ішлі к калодзежу» (ПЭЗ 2011: 227).

Объективация библейской истории происходит с помощью сакральных (культовых) элементов ландшафрта, поскольку «сакральные топосы, которые отображены в фольклорной истории, играют роль организационного ядра на уровне поселения и в масштабах локального, регионального и общеэтнического пространства» (Демирев 2007: 7).

Значительная часть легенд и преданий относятся к временам божественной креации, когда мир по высшей воле принимал свои окончательные очертания. Иными словами, разговор идет о мифическом времени, когда Бог (Матерь Божья) ходили по земле. «Следы» святых странников в большинстве случаев и являются доказательством присутствия божественных персонажей в границах обычных деревенских околиц, что наиболее рельефно проявилось в чествовании многочисленных камней-следовиков - валунов с природными или искусственно созданными выемками, которые напоминают след человеческой ступни. Исследователь сакральной географии Беларуси Э. Левков отметил, что «следы принимали за "вещественные доказательства" нахождения небожителей на белорусской земле. Чаще всего вспоминают Деву Марию: камни След Багалаиі, След Прасвятой Багародзіцы, Ступня Багалаиі, След Маткі Божай и т.д. Много валунов с названиями Боскі Слядок, Боская Ножка, След Хрыста.... Иногда следы соотносят со святыми Николаем, Петром, ангелами (Ляўкоў 1992: 149-150).

Ландшафтные объекты такого рода воспринимаются местным населением не просто как сакрально выделенные, но чудодейственные, что лежит в основе их священного статуса и соответственных ритуальных фрункций.

Там, дзе Падрэзы, на полі недалёка і быў той Сьвяты камень. Зваўся так, што на ім сьлядочкі былі такія: кругловінка, як ад каленкі, і маленькая пятачка дзецкая. Гэта гаварылі, што даўным-даўно ішла па гәтым полі Багародзіца з сынам, і спатыкнуліся аб гәты камень. I сьлядочкі тыя засталіся: Багародзіцы і маленькага Ісуса Хрыста. Тая вадзічка (которая оставалась в следах - В. Л.), гаварылі, дужа памагае ад усякіх хваробаў (Бешенковичский р-н) (ПЭЗ 2011: 236). 


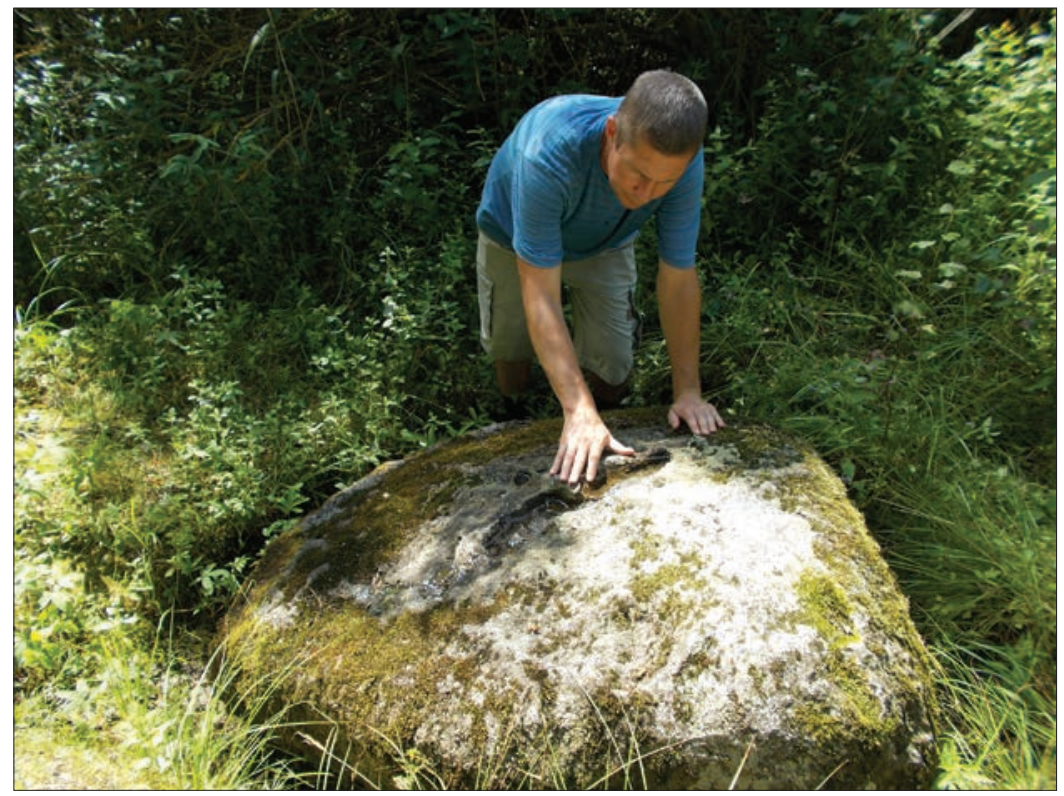

Святой (Богов) камень-следовик возле д. Великий Полсвиж Лепельского р-на Витебской обл. Фото Володиной Т.В., 2014 г.

В качестве объектов божественной креации, в результате чего они и получили свою святость, часто фригурируют и культовые источники, сакральность которых «верифицируется» местным сообществом в рамках календарных праздников.

Крыніца Ізус завецца. Ну, Ісус Хрыстос. Можа Ісус тую ваду асвяціў. Так гаварылі. Як раньшэ малыя былі, у школу хадзілі, дык там палаценцы віселі. Крэст такі стаяў, палаценца вісела і лажылі капейкі. Крэст і там полачка. I цяпер ложуць. Там з-пад зямлі б’е фантанчык і вада цераз балота і ў рэчку цячэ. Хадзілі ў Чысты чацверг. Нада да сонца схадзіць, вады набраць, памыщца, каб дзяўчына красівай была, штоб харошы малец замуж узяў. Хадзілі і перад Калядамі. Перад Пасхай абязацельна (Чашникский р-н) (ПЭЗ 2011: 203).

Сакральный статус «божественных путников» проявляется и в том, что они, в отличие от обычных людей, способны оставить свои следы там, где человеку их оставить в принципе невозмож- 


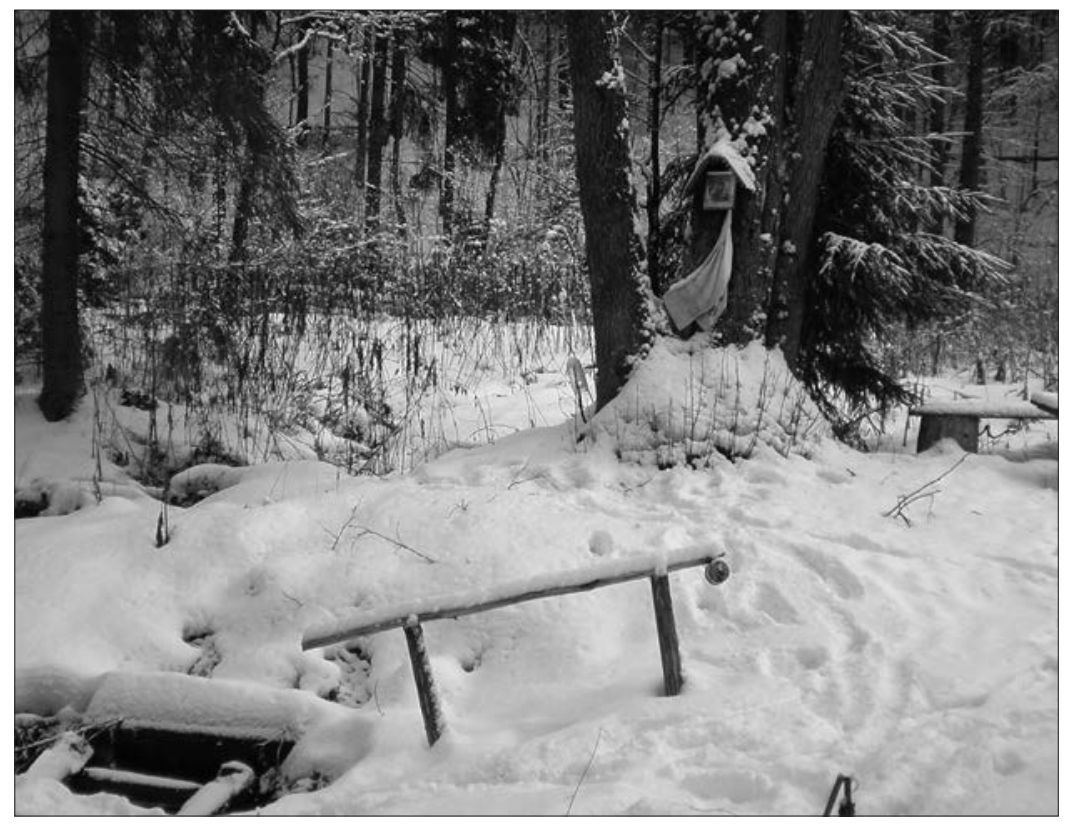

Культовый источник Изус возле д. Вишковичи Чашникского р-на Витебской обл. Фото автора, 2009 г.

но. Легенды о следах (дороге), которые оставила Богородица на поверхности озера, бытуют в различных регионах Беларуси.

В Мокранах слыдкі на камэні. Тыі слыдкі і полоса чэрэз озэро, як станэш дывытыся. Як самолёт пролетыть, так і чәрэз озеро. Матер Божа ішла з того камня чэрэз тое озэро. То ходылы молытыся Богу. Это Малорыщкі раён. На Дэсятуху народ ідә отовсюль (ТМКБ 2011: 460)

Была ля (возера) Велье царква. Ну, і адным разам правалілася пад зямлю. А Багародзіца пашла прама па возеру. I дзе шла яна, там і засталася дарога (ПЭЗ 2011: 175).

Результатом созидательной деятельности странствующего Бога могут быть и селения людей, названия которых отображают обстоятельства божественного пути на земле.

Шоў Ісус Хрыстос па балоце, астанавіўся ў Бяседах, там вёў бяседу, так і назвалі дзярэўню. У Сітніках далі яму сітнага хлеба, так і стала дзярэўня называцца» ${ }^{5}$. 
Вероятно, что схожую легендарную этимологию имели деревни з названием Багі, Богаўшчына, Богінка, Божа Ласка, Божая Воля, которые существовали на территории Беларуси, но исчезли во времена советской власти (Генкін 2009: 630-631).

\section{Заключение}

Элементы традиционного культурного ландшафта в совокупности с топонимическим фольклором являют собой цельный механизм объективации истории, когда события далекого или близкого прошлого предметно олицетворяются и маркируются конкретными объектами реального пространства, становятся максимально наглядными и понятными. При этом объективация истории, которая в известной степени характерна и для письменного (городского) общества (исторические памятники, памятные доски, мемориалы являются обязательными чертами любого городского ландшафта), в рамках традиционного сообщества происходит по собственным законам, когда первичным и важным становится знаковость того или иного исторического события именно для локальной истории.

Топография фольклорной истории выясняет и особенности семиотизации разных сегментов культурного ландшафта. В то время как символические и информационные функции «поля культуры», зоны подчеркнуто антропогенной (поселение и все его структурные элементы), обслуживают прежде всего актуальную историю сообщества, то в качества опредмеченного фонда эпической истории выступают, прежде всего преимущественно, природные объекты: горы, камни, источники, озера, лесные урочища, а также археологические памятники. Курганы и городища, хотя и рассматриваются в мифопоэтической картине мира как объекты, созданные людьми, но соотносятся с категорией «чужого» и локализуются преимущественно в природной зоне. Указанная особенность подчеркивает взаимосвязь и взаимодополняемость всех элементов культурного ландшафта в рамках единой интегральной картины мира, которая является механизмом и способом истолкования действительности не только в синхронной, но и диахронной перспективе.

Таким образом, объекты традиционного культурного ландшафта фокусируют и репрезентируют наиболее знаковые 
и важные события локальной истории, осмысленной в фольклорном русле. Региональные особенности белорусской истории находят отображение в фольклорных нарративах (война со шведами или французами) при том, что категории ландшафртных объектов природных (озеро, пригорок, источник) либо антропогенных (курганы, городища) остаются неизменными.

\section{Примечания}

1 Зап. автором в 2012 г. в д. Новодруцк Поставского р-на Витебской обл. от Юхнович А. Ю., 1931 г. р.

2 Зап. автором в 1995 г. в г. п. Освея Вернедвинского р-на Витебской обл. от Зайцевой М. Ф., 1922 г. р.

3 Зап. автором в 2015 г. в д. Михалово Чашникского р-на Витебской обл. от Муравицкого А. Ф., 1942 г. р.

4 Зап. А. Картэнка в 2004 г. в д. Росица Верхнедвинского р-на Витебской обл. от Хадзюк Лидии Михайловны, 1914 г. р.

5 Зап. В. Тухта в 2009 г. в д. Ситники Лепельского р-на Витебской обл. от Скорба К. И., 1928 г. р.

\section{Литература}

Аникиевич, Кирилл 1907. Сенненский уезд Могилевской губернии. Могилев: Губернская типография.

Байбурин, Альберт 1993. Ритуал в традиционной культуре: Структурно-семантический анализ восточнославянских обрядов. СПб: Наука.

Барысевіч, Фёдар 1972. Курганы славы. Беларуская савецкая эниыклапедыя У 12 m. Т. 6. Мінск: БелСЭ, сс. 212-215.

Белова, Ольга \& Петрухин, Владимир 2008. Фольклор и книжность: мифб и исторические реалии. Москва: Наука.

Генкін, Уладзімір 2009. Назвы населеных пунктаў Рэспублікі Беларусь: Віцеб. вобл.: нармат. давед. У. М. Генкін, І. Л, Капылоў, В. П. Лемцюгова (ред.). Мінск: Тәхналогія. 
Демирев, Владимир 2007. За сакралните топоси във фолклорнота история. Български фболклор 3, сс. 7-17.

Дучыц, Людміла 1993. Археалагічныя полнікі у назвах, вераваннях $i$ паданнях беларусаў. Мінск: Навука і тәхніка.

Дучыц, Людміла \& Клімковіч, Ірына 2011. Сакральная геаграфбія Беларусі. Мінск: Літаратура і Мастацтва.

Жукас, Саулюс 1982. Ці абнаўляе фральклор літаратуру? Узроўні фбальклорных уплыьаў. Зборнік. Мінск: Навука і тәхніка, сс. 70-84.

Збор 1985. Збор помнікаў гісторыі і культуры Беларусі. Віцебскал вобласць. Мінск: БСЭ.

Легенды 2005. Легенды і паданні. Мінск: Беларуская навука.

Лобач, Уладзімір 2013. Міфб. Прастора. Чалавек: традыцыйны культурны ландшафт беларусаў у селіятычнай перспектыве. Мінск: Тәхналогія.

Ляўкоў,Эрнст 1992. Маўклівыл сведкі мінуўшчыьны. Мінск: Навука і тәхніка.

Неклюдов, Сергей 2007. Заметки об «исторической памяти» в фольклоре. АБ-60. Сборник статей к 60-летию А. К. Байбурина. СПб: Европейский университет, сс. 77-86.

Панченко, Александр 1998. Исследования в области народного православия. Деревенские святыни Северо-Западной России. СПб: Алитейя.

Пропп, Владимир 1976. Фольклор и действительность. Москва: Наука.

ПЭ3 2011.Полацкі этнаграфбічны зборнік. Вып. 2. Народная проза беларусаў Падзвіння: у 2 ч. Ч. 1. Наваполацк: Полацкі дзяржаўны ўніверсітэт.

Слоўнік 1980. Слоўнік беларускіх гаворак паўночна-заходняй Беларусі $i$ яе пагранічча: у 5 т. Т. 2. Мінск: Навука і тәхніка.

ТМКБ 2006. Традыцыйная мастацкая культура беларусаў: у 6 т. Т. 3 : Гродзенскае Панямонне: у 2 кн. Кн. 2. Мінск: Вышәйшая школа.

ТМКБ 2011. Традыцыйная мастацкая культура беларусаў: у 6 т. Т. 5 : Цэнтральная Беларусь: у 2 кн. Кн. 2. Мінск: Вышәйшая школа. 
Штырков, Сергей 2003. Опыт изучения сельских святынь. Живая старина 3, с. 18.

Pelcowa, Halina 2005. Przestrzeń jako sposób postrzegania świata przez užytkowników gwary. Przestrzeń wjęzykuiwkulturze. Problemy teoretyczne interpretacje tekstów religijnych. Lublin: Wyd-wo UMCS, cc. $125-135$.

Radzik, Ryszard 2000. Miedzy zbiorowoscia etniczna a wspólnota narodowa: Bialorusini na tle przemian narodowych $w$ Europie Srodkowo-Wschodniej XIX st. Lublin: Wyd-wo Uniwersitetu M.CurieSklodowskiej.

\section{Summary}

\section{Belarusian Traditional Cultural Landscape Elements as a Means of History Objectivation}

\section{Vladimir Lobach}

Keywords: Belarusian traditional culture, cultural landscape, folklore, history, history objectivation, mythology of space, sacred geography

In the mythopoetic world view natural and man-made objects of the traditional cultural landscape act as "braces" of collective memory and life experience which constantly verify and invoke the past in its most important societal dimensions. In the framework of Belarusian traditional society, the objectivation of history is an extremely important symbolic function of a cultural landscape. But the mechanism of filtering and recording historical events, which includes a real-life object and the related folkloric semantic constructs, is different from the logic and the rules of "written history". In the framework of local community, the significance of a certain historical event is of primary importance while the chronological correlation is secondary and unimportant. The landscape objectivation focuses on recording and "processing" mythological precedents and epochal historical events. Various levels of personalization of historical events and their projections on local cultural landscape call for historicentric interpretations of this landscape where the most significant historical events (from biblical flood to Napoleonic War) take place near a specific village. Collective memory not only clearly explains the events of the past through folklore legends that are correlated with the landscape elements, but also "places" local history in the center of the global biblical and world history. 


\section{МИССИЯ ВЫПОЛНИМА Перспективы изучения фольклора}

http://www.folklore.ee/rl/pubte/ee/sator/sator19/

ISSN 1736-0323

ISBN 978-9949-586-60-8

DOI: $10.7592 /$ Sator.2018.19

Тарту 2018

Редакторы-составители выпуска:

Маре Кыйва \& Татьяна Володина

Редактор серии: Маре Кыйва

Фото: Яак Кикас, 2018 «Осень в Тарту»

Оформление обложки: Лииса Весик

Верстка \& HTML: Диана Кахре

Печатное издание: МИССИЯ ВЫПОЛНИМА:

Перспективы изучения фольклора. SATOR 19. Тарту 2018

Публикация книги осуществлена совместно Эстонским литературным музеем и Центром исследований белорусской культуры, языка и лит ерат уры Националь ной акад емии наук Б еларус и, п ри поддержке Министерства образования и науки Эстонии (IUT 22-5), Фонда регионального развития ЕС (ТK 145, Центр компетенции по Эстонским исследованиям); при поддержке проекта, финансируемого Министерством иностранных дел Эстонии из бюджета по сотрудничеству и развитию, Эстонской Академией Наук и Национальной академии наук Беларуси.

Оформление электронного издания осуществлено при поддержке проекта ЕККМ14-344 “Расширение областей применения и представление эстонского языка, культуры и фольклора в электронных информационных средствах".

() Эстонский литературный музей

(c) Авторы

(с) Яак Кикас 